\title{
Assessment of hydraulic conductivity and soil quality of similar lithology under contrasting landuse and land cover in humid tropical Nigeria
}

\author{
Ernest Iheanyi Chidozie $^{* 1}$, Irokwe Frida Ifeanyi ${ }^{1}$, Okafor Maduabuchi Johnbosco ${ }^{2}$, Irondi Aaron Onyekachi ${ }^{3}$, Chime \\ Chidubem Anthony, Okeke Marcellinus Obinna ${ }^{4}$, Njoku Ugochi Gift ${ }^{5}$, Dibofori George ${ }^{1}$, Agbugba Stanly Emeka ${ }^{1}$, Taqi \\ Raza $^{6}$ and Michael Oluebube Glory ${ }^{7}$ \\ ${ }^{1}$ Soil Science and Technology, Federal University of Technology, Owerri, Nigeria \\ ${ }^{2}$ Agricultural Technology, Anambra State Polytechnic Mgbakwu, Nigeria \\ ${ }^{3}$ Soil Science and Meterology, Michael Okpara University of Agriculture, Umudike, Nigeria \\ ${ }^{4}$ Agricultural and Bio-Environmental Engineering, Institute of Management Tech. Nigeria \\ ${ }^{5}$ Agricultural Technology, Federal Polytechnic Nekede, Nigeria \\ ${ }^{6}$ University of Agriculture Faisalabad Sub Campus Burewala, Pakistan \\ ${ }^{7}$ Agronomy and Ecological Management, Enugu State University, Enugu, Nigeria
}

\begin{abstract}
The study assessed hydraulic conductivity and soil quality of some tropical soils of Nigeria. Field studies were carried out in eight Local Government Areas of Imo State with contrasting land use and similar lithology (coastal plain sands). These included Owerri west (Bare fallow) Mbaitoli (Industrial Area), Owerri Municipal (Residential Area), Ohaji/Egbema (Cassava Cultivated), Ikeduru (Oil Palm Plantation), Ngor-Okpala (Continuous Cultivated), Aboh-Mbaise (Excavated Site) and Owerri North (Bush Fallow/Control). Top soil samples of 0-20cm were collected from each land use type. Soil sample was also collected in fallow plot as a tool for comparison. Soil samples were air dried and sieved for standard laboratory analysis. Data obtained were subjected to statistical analysis. Results showed nutrient depletion in soils of all land uses compared to the fallow plot. Sand content $(812.3 \mathrm{~g} / \mathrm{kg})$ dominated the texture of all soils studied. All soils studied had slightly acidic soil reaction with mean value of 4.73. With regard to hydraulic conductivity, following the land degradation index (LDI,) high land degradation was observed in the excavated site (-92.9), Residential Area (-87.3) and Industrial Area (-84.1) with corresponding higher bulk densities and lower soil porosity compared to other soils .Generally, soils of the excavated site were highly degraded, followed by the residential area, industrial area, continuous cultivated area, cassava cultivated plot, oil palm plantaion and bare fallow plot, respectively. Dense population, blank utilization of lands, soil mismanagement, deforestation, high temperature and rainfall, intensive cultivation were observed to have aided the decline of soil quality. Adoption of night soil technology as well as other organic and climate smart agricultural practices should be encouraged.
\end{abstract}

Keywords: Hydraulic conductivity, soil quality, land use, humid tropics, Nigeria

\section{Introduction}

The severity of land degradation characterized by decreased land productivity, diminution of biodiversity and loss of $\mathrm{CO}_{2}$ sink are of global concern. International summits such as 'Our Common Future' (1987), The 'Rio Declaration' and 'Agenda 21' (1992) and the 'Johannesburg Declaration' (2002) created the awareness that concerted efforts were needed to develop sustainable land use practices and minimize the deterioration of natural resources and biodiversity (World Bank, 2001).

Lands have been utilized intensively for all purposes at the expense of their suitability, which have resulted in massive land degradation (Senjobi and Ogunkunle, 2011).
FAO (1984) observed that about $20 \%$ of the world's agricultural lands have been irreversibly damaged due to accelerated land degradation and intensive land use, leading to a reduction of about $15-30 \%$ of their productivity.

Demographic pressure with its attendant increase in food demand has resulted in the expansion and intensification of land use systems in tropical Nigeria which consequently increases abiotic pressure of which soil quality is among the most important (Lal, 1993). Many researchers have reported that the conversion of natural forest to other forms of land use can result to soil erosion, modification of soil structure, reduction in soil organic matter and soil hydraulic conductivity.

\footnotetext{
*Email: taqiraza85@gmail.com
} 
Hydraulic conductivity is fundamental for modeling drainage and movement of moisture within the soil matrix either as saturated or vapour flow. Intensity in land use and land cover change from bushland settings to other forms has the potential to cause dramatic disturbances to the soil and impede the free movement of water through the pores which leads to surface runoff, erosion and downstream pollution.

A success in soil management to maintain soil quality depends on the understanding of how the soil responds to agricultural practices and other land uses over time. Recent interest in evaluating the quality of our soil resource has therefore been simulated by increasing awareness that soil is critically an important component of the earth's biosphere, functioning not only in the production of food and fiber, but also in the maintenance of local, regional, and global environmental quality (Negassa, 2001).

There is a growing need for information relating to soil conditions, their current status, changes due to land use and management practices (Wilson et al., 2008). In tropical Nigeria, indiscriminate land utilization without adequate land and soil evaluation has given rise to serious ecological problems and degradation of land resources. This triggered the study on the assessment of hydraulic conductivity and soil quality of similar lithology under contrasting landuse and land cover in humid tropical Nigeria.

\section{Materials and Methods}

The study was conducted in Imo State, located in the humid tropical southeast region of Nigeria and lies between latitudes $5^{0} 15^{1} \mathrm{~N}$ and $5^{0} 45^{1} \mathrm{~N}$, and longitude $6^{0} 45^{1} \mathrm{E}$ and $7^{0} 15^{1} \mathrm{E}$ with an elevation of $91 \mathrm{~m}$ above sea level which covers over $5,530 \mathrm{~km}^{2}$. The hydrology of the study area is governed by Imo River and other rivers such as Nworie, Ogochie, Otamiri, Oramirukpa, and Mba rivers etc.

The major parent material of Imo state is the coastal sands and flood plains (Benin formation and deltaic deposits) and marine deposits. Others are the Ameki formation, Imo shale and Nsukka formation. The study area lies within the humid tropics. The mean temperature range is from $26-29^{\circ} \mathrm{C}$. The relative humidity is high throughout the year especially in rainy season averaging $85 \%$. The mean annual rainfall over years ranges from $2500-3000 \mathrm{~mm}$ which is attributed within 9-month period which starts from March and ends September, while the dry season is from November to February (Ofomata, 1975).

The natural vegetation of the study area is tropical rainforest. The plant species are arranged in tiers with the forest floor harbouring a great category of sun heating species. The rain forest is highly depleted of plant species due to human activities. The dominant exploitable flora are
Iroko (Milicia excelsa), Mahogany (Khaya anthotheca), Obeche (Triplochiton scleroxylon), Rubber (Hevea brasiliensis) and Oil palm (Elaeis guineensis), others include; Oil bean tree (Perntaclethra macrophyla), Gmelina (Gmelina aborea), Butterfly pea (Centrosema pubescens), Raffia palm (Raphia ferinifera), Wine palm (Butia capitata), Water fern (Histiopteris incisa), Cassava (Manihot esculenta.), Yam (Dioscorea alata.). Cereals and grasses include; Elephant grass (Pennisetum purpurenum,), Giant star grass (Cynodon plectostachyus), Siam weed (Chromolaena odorata), Goat weed (Ageratum conyzoides) and clusters of bamboo and shrubs.

\section{Field Work}

A reconnaissance visit was carried out with the aid of a location map of the study area to identify the areas to be studied. A combination of target and random sampling techniques guided field studies. Soil samples were collected from eight local government areas of same lithology (coastal plain sands) with distinct land uses. These include: Owerri West (Bare fallow area), Ohaji/Egbema (Cassava cultivated), Owerri Municipal (Residential area), Mbaitoli (Industrial area), Ngor Okpala (Continuous cultivated), Ikeduru (Oil palm plantation), Aboh-Mbaise (Excavation site) and Owerri North (Bush Fallow/control).

Top soil samples of $0-20 \mathrm{~cm}$ were collected and tested for some physical and chemical properties using standard laboratory procedures. Core soil samples were also collected from each study site to determine bulk density using the Grossman and Reinsch (2002) method. Particle size distribution was determined by hydrometer method according to the procedure of Gee and or (2002). Hydraulic conductivity was determined using the Obi (2000) procedures. Organic carbon was determined using wet oxidation method described by Nelson and Sommers (1982). Exchangeable bases (magnesium, calcium, sodium and potassium). Exchangeable $\mathrm{Na}$ and $\mathrm{K}$ were extracted using $1 \mathrm{~N}$ NH4OAc using flame photometer (Jackson, 1964), while $\mathrm{Ca}$ and $\mathrm{Mg}$ were determined using ethelene diamine tetracetic acid (EDTA) (Thomas, 1988). Exchangeable acidity was determined titrimetrically (Mclean, 1982). Effective cation exchange capacity (ECEC) was calculated from the summation of all exchangeable bases and exchangeable acidity (Soil Survey Laboratory Staff, 1992). Percentage base saturation (\%BS) was determined by computation.

Data collected from the study site were subjected to summary statistics such as Mean. Also, Coefficient of variation $(\mathrm{CV})$ was used to estimate the degree of variability existing among soil properties in the study site. Coefficient of variation was ranked as follows; low variation $\leq 15 \%$, 
Ernest, Irokwe, Okafor, Irondi, Chime, Okeke, Njoku, Dibofori, Agbugba, Taqi and Michael

moderate variation $15 \% \leq 35 \%$ and high variability $>35 \%$ (Wilding et al., 1994).

\section{Land degradation determination}

Status of land degradation was computed from results of laboratory analyses of samples from all land uses and compared with forest soils, using the land degradation index (Barrow, 1991). The LDI is given as follows:

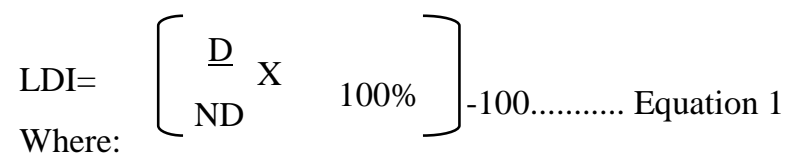

LDI $=$ Land degradation index

$\mathrm{D}=$ Value of soil parameter of each land use

$\mathrm{ND}=$ Value of soil parameter in the non -degraded tract/forest plot

$100 \%=$ Percentage grade

$100=$ Constant representing ideal soil state

\section{Results and Discussion}

Sand played a significant role in the particle size distribution of the soils studied having high content which was attributed to the coastal plain sand lithology of the resulting to compaction and consequent reduction of soil pores $(35.1 \%),(35.9 \%)$ and $(30.0 \%)$, respectively. Bulk density recorded in cassava cultivated area $\left(1.39 \mathrm{~g} / \mathrm{cm}^{3}\right)$, oil palm plantation $\left(1.76 \mathrm{~g} / \mathrm{cm}^{3}\right)$ and continuous cultivated plot $\left(1.33 \mathrm{~g} / \mathrm{cm}^{3}\right)$ were attributed to pre and post planting operations as well as intense precipitation and quick oxidation of organic matter as soil porosity recorded $47.7 \%$, $34.0 \%$ and $50.0 \%$, respectively. High bulk density restricts poor movement of water and air, lodging and rotting of plant root, reduces crop emergence, impedes root growth and limits soil exploration by roots leading to poor plant growth, influencing crop yield and reducing vegetation cover available to protect the soil from erosion (Arshad et al., 1996). Akamigbo (1999) reported that low soil organic matter was responsible for increased bulk density in cultivated soils of Southeastern Nigeria. Bare fallow and bush fallow areas recorded lower bulk densitities of $0.93 \mathrm{~g} / \mathrm{cm}^{3}$ and $0.99 \mathrm{~g} / \mathrm{cm}^{3}$, respectively, with soil porosity of $65.6 \%$ and $62.2 \%$ due to higher organic matter hence higher specific surface area of the soils. Table 1.

Soils formed from coastal plain sands are characterized by high porous medium. However, hydraulic conductivity of all soils studied ranged between $0.009-0.126 \mathrm{~kg} / \mathrm{S}$. Higher hydraulic conductivity were observed in the bare

Table 1: Physical properties of the selected soil

\begin{tabular}{lcccccccc}
\hline Location & $\begin{array}{c}\text { Depth Sand } \\
\text { cm }\end{array}$ & $\begin{array}{l}\text { Silt } \\
\text { g/kg }\end{array}$ & Clay & $\begin{array}{l}\text { Textural } \\
\text { class }\end{array}$ & $\begin{array}{c}\text { B.D } \\
\text { g/cm }\end{array}$ & $\begin{array}{c}\text { Porosity } \\
\mathbf{\%}\end{array}$ & $\begin{array}{l}\mathbf{K}_{\text {sat }} \\
\text { Kg/S }\end{array}$ \\
\hline Owerri West (Bare fallow area) & $0-20$ & 844.0 & 50.0 & 106.0 & SL & 0.93 & 65.6 & 0.100 \\
Mbaitoli (Industrial area) & $0-20$ & 858.0 & 40.1 & 101.0 & SCL & 1.72 & 35.1 & 0.020 \\
Owerri Municipal (Residential area) & $0-20$ & 809.0 & 90.0 & 101.0 & SCL & 1.70 & 35.9 & 0.016 \\
Ohaji/Egbema (Cassava cultivated) & $0-20$ & 839.0 & 35.0 & 126.0 & SL & 1.39 & 47.7 & 0.055 \\
Ikeduru (Oil Palm Plantation) & $0-20$ & 788.0 & 80.0 & 132.0 & SCL & 1.76 & 34.0 & 0.072 \\
NgorOkpala (Cultinuous cultivated) & $0-20$ & 861.0 & 52.4 & 86.6 & SL & 1.33 & 50.0 & 0.047 \\
Aboh-Mbaise (Excavated site) & $0-20$ & 608.0 & 80.0 & 312.0 & SCL & 1.21 & 30.0 & 0.009 \\
Owerri North (BushFallow/control) & $0-20$ & 891.0 & 50.0 & 59.0 & S & 0.99 & 62.2 & 0.126 \\
\hline Mean & & $\mathbf{8 1 2 . 3}$ & $\mathbf{5 9 . 7}$ & $\mathbf{1 2 8 . 0}$ & SL & $\mathbf{1 . 3 8}$ & $\mathbf{4 5 . 1}$ & $\mathbf{0 . 0 5 6}$ \\
\hline CV\% & & $\mathbf{1 0 . 9}$ & $\mathbf{3 4 . 6}$ & $\mathbf{6 0 . 8}$ & $\mathbf{2 3 . 7}$ & $\mathbf{3 0 . 0}$ & $\mathbf{7 5 . 3}$ \\
\hline
\end{tabular}

B. $\mathrm{D}=$ Bulk density, Texture: $\mathrm{SL}=$ Sandy loam, $\mathrm{SCL}=$ Sand Clay Loam., $\mathrm{S}=$ Sand, Ksat=Hydraulic Coductivity

study area. However, there were decreases in sand content and subsequent increase of silt and clay content in the industrial area, residential area, oil palm plantation and excavated site. The increase in clay and silt were due to the anthropogenic activities of the area which led to the removal of top soil and sub soil exposure. The bulk density of the soils studied ranged between $0.93-1.76 \mathrm{~g} / \mathrm{cm}^{3}$ which indicates mineral soil dominance of the studied areas. High bulk density observed in the industrial area $\left(1.72 \mathrm{~g} / \mathrm{cm}^{3}\right)$, residential area $\left(1.70 \mathrm{~g} / \mathrm{cm}^{3}\right)$, and excavated site $(1.21$ $\mathrm{g} / \mathrm{cm}^{3}$ ) were due to human disturbance such as vehicular traffic and mounting structures on soil and top soil removal fallow $(0.100 \mathrm{~kg} / \mathrm{S})$ and bush fallow $(0.126 \mathrm{~kg} / \mathrm{S})$. This is due to the presence of leaf litter which catalyses krotovinal activities through decomposition which creates more porous medium in soils. Oil palm plantation $(0.072 \mathrm{~kg} / \mathrm{S})$, cassava cultivated $(0.055 \mathrm{~kg} / \mathrm{S})$ and continuous cultivated $(0.047 \mathrm{~kg} / \mathrm{S})$ plots recorded moderate hydraulic conductivities due to higher bulky densities and lower soil porosity. However, in the oil palm plantation, the presence of fibrous and adventitious roots through its moisture and nutrient interception created pores within the soil medium. Industrial $\quad(0.020 \mathrm{~kg} / \mathrm{S})$, residential $(0.012 \mathrm{~kg} / \mathrm{S})$ and excavated site $(0.009 \mathrm{~kg} / \mathrm{S})$ recorded the least hydraulic 
conductivities due to compaction and sealing of soil pores. This could result to moisture surface runoff, erosion and offsite-downstream pollution. Soils of all areas studies showed slightly acidic reaction which ranged between 4.58 $6.46\left(\mathrm{H}_{2} \mathrm{O}\right)$ and 4.09-5.58 $(\mathrm{KCl})$. However, the soils were negatively charged at their neutral $\mathrm{pH}$ since the $\mathrm{pH}$ values in water suspension were greater than the corresponding $\mathrm{pH}$ values in $1 \mathrm{~N} \mathrm{KCl}$ solution. Hence, delta $\mathrm{pH}$ was positive in all soils studied. Acidic soil reaction in the areas studied indicates the dominance of $\mathrm{Al}^{3+}$ and $\mathrm{H}^{+}$ions in the soil exchange complex. Low $\mathrm{pH}$ recorded in the soils could be attributed to leaching of basic cations out of the soil solum and corresponding increase in $\mathrm{H}^{+}$ions on the exchange sites (Soil Survey Staff, 2003). Others could be a result of loss of bases through crop removal and formation of carbonic acid through $\mathrm{CO}_{2}$ released by roots and microorganisms and atmospheric acidic substances in soil through acid rain. Variation in organic matter content of soils studied with respect to land use was observed. Bare fallow (2.65\%) and bush fallow $(2.32 \%)$ recorded the highest organic matter contents due to high litter fall and incorporation of organic residues into the soil. Also, the vegetative cover in the bush fallow impeded direct impact of the tropical climate which restricted leaching and quick oxidation of organic matter. Cassava cultivated area and oil palm plantation recorded organic matter values of $1.55 \%$ and $1.14 \%$, respectively, which could be attributed to the rapid mineralization of organic matter, plant uptake, intense leaching as well as bush burning pre-planting operation. Low organic matter recorded in the excavation site $(1.41 \%)$ was a result of excavation activities hence the removal of fertile surface soils. The residential and industrial areas recorded organic matter values of $1.14 \%$ and $0.82 \%$, respectively, which was attributed to deforestation, removal of surface soils and exposure of soils to harsh tropical climate. The continuous cultivated plot recorded the least organic matter values $(0.69 \%)$ due to incessant intense cultivation without fertility replenishment, an act which could be termed agricultural soil mining.

Total exchangeable acidity values observed in excavation site $(3.4 \mathrm{cmol} / \mathrm{kg})$ and oil palm plantation plots $(2.4 \mathrm{cmol} / \mathrm{kg})$ were very high above the critical value of 2.0 $\mathrm{cmol} / \mathrm{kg}$ which may affect sensitive crops. Acidity affects plant growth by decreasing the availability of plant nutrients

Table 2: Chemical properties of the selected soil

\begin{tabular}{|c|c|c|c|c|c|c|c|c|c|c|c|c|c|}
\hline Location & $\begin{array}{l}\text { Depth } \\
\text { (cm) }\end{array}$ & $\begin{array}{l}\mathrm{pH} \\
\mathrm{H}_{2} \mathrm{O}\end{array}$ & $\begin{array}{l}\text { pH } \\
\text { KCl }\end{array}$ & $\begin{array}{l}\text { O.M } \\
\%\end{array}$ & TEA & $\mathrm{Ca}^{+} \mathrm{Mg}^{+}$ & $\begin{array}{c}\mathrm{K}^{+} \\
\mathrm{Cmol} / \mathrm{k}\end{array}$ & $\mathrm{Na}^{+}$ & TEB & ECE & $\begin{array}{c}\text { CBS } \\
\%\end{array}$ & $\begin{array}{l}\text { T.N } \\
\%\end{array}$ & $\begin{array}{l}\text { Av.P } \\
\text { ppm }\end{array}$ \\
\hline Owerri West (Bare fallow area) & $0-20$ & 578 & 5.20 & 2.65 & 1.0 & 1.50 .3 & 0.22 & 0.24 & 1.99 & 2.99 & 66.5 & 0.02 & 3.80 \\
\hline Mbaitoli (Industrial area) & $0-20$ & 5.80 & 4.86 & 0.82 & 0.9 & 1.10 .6 & 0.18 & 0.14 & 2.02 & 2.92 & 69.2 & 0.03 & 2.21 \\
\hline Owerri Municipal (Residential area) & $0-20$ & 5.96 & 5.26 & 1.14 & 1.4 & 1.30 .5 & 0.18 & 0.19 & 2.17 & 3.57 & 60.8 & 0.04 & 1.67 \\
\hline Ohaji/Egbema (Cassava cultivated) & $0-20$ & 6.46 & 5.58 & 1.55 & 2.0 & 1.90 .4 & 0.01 & 0.02 & 2.33 & 4.33 & 53.8 & 0.01 & 4.84 \\
\hline Ikeduru (Oil Palm Plantation) & $0-20$ & 4.58 & 4.23 & 1.14 & 2.4 & 2.01 .4 & 0.21 & 0.16 & 3.77 & 6.17 & 61.1 & 0.05 & 0.72 \\
\hline NgorOkpala (Cultinuous cultivated) & $0-20$ & 5.23 & 4.11 & 0.69 & 2.0 & 0.40 .1 & 0.08 & 0.22 & 0.74 & 2.78 & 26.6 & 0.06 & 1.03 \\
\hline Aboh-Mbaise (Excavated site) & $0-20$ & 4.66 & 4.09 & 1.41 & 3.4 & 1.91 .6 & 0.20 & 0.19 & 3.89 & 7.29 & 53.4 & 0.01 & 5.00 \\
\hline Owerri North (Bush Fallow/control) & $0-20$ & 5.40 & 4.50 & 2.32 & 0.8 & 2.61 .2 & 0.21 & 0.09 & 4.10 & 4.90 & 83.7 & 0.02 & 6.77 \\
\hline Mean & & 5.48 & 4.73 & 1.47 & 1.74 & $\begin{array}{lll}1.6 & 0.8 \\
\end{array}$ & 0.16 & 0.16 & 2.63 & 4.37 & 59.4 & $\mathbf{0 . 0 3}$ & 3.26 \\
\hline CV\% & & 12 & 12 & 47 & 51 & 4273 & 47 & 46 & 45 & 38 & 28 & 62 & 67 \\
\hline
\end{tabular}

Table 3: Land Degradation Index (LDI) of selected soil

\begin{tabular}{lccccccc}
\hline Location & O.M & HC & TEB & ECEC & BS & T. N & Av. P \\
\hline Owerri West (Bare fallow area) & 14.2 & -20.6 & -51.5 & -39.0 & -20.5 & 0 & -43.8 \\
Mbaitoli (Industrial area) & -64.7 & -84.1 & -50.7 & -40.4 & -17.3 & 50 & -67.4 \\
Owerri Municipal (Residential area) & -50.9 & -87.3 & -47.1 & -27.1 & -27.4 & 100 & -75.3 \\
Ohaji/Egbema (Cassava cultivated) & -33.2 & -56.3 & -43.2 & -11.6 & -35.7 & -50 & -28.5 \\
Ikeduru (Oil Palm Plantation) & -50.9 & -42.9 & -8.0 & 25.9 & -27.0 & 150 & -89.4 \\
NgorOkpala (Cultinuous cultivated) & -70.3 & -63.0 & -82.0 & -43.3 & -68.2 & 200 & -84.8 \\
Aboh-Mbaise (Excavated site) & -39.2 & -92.9 & -5.1 & 48.8 & -36.2 & -50 & -26.1 \\
Owerri North (Bush Fallow/control) & 0 & 0 & 0 & 0 & 0 & 0 & 0 \\
\hline
\end{tabular}

$\mathrm{OM}=$ Organic matter, $\mathrm{T} . \mathrm{N}=$ Total nitrogen, $\mathrm{TEB}=$ Total exchangeable bases, $\mathrm{ECEC}=$ Effective cation exchange capacity, $\mathrm{BS}=\mathrm{Base}$ saturation, Avail. $\mathrm{P}=$ Available phosphorus, $\mathrm{HC}=\mathrm{Hydraulic}$ Conductivity. 
Ernest, Irokwe, Okafor, Irondi, Chime, Okeke, Njoku, Dibofori, Agbugba, Taqi and Michael

such as $\mathrm{P}$ and $\mathrm{Mo}$ as well as other basic cations and increasing the availability of some elements to toxic levels particularly $\mathrm{Al}$ and $\mathrm{Mg}$. The cassava plot and continuous cultivated plots recorded $2.0 \mathrm{cmol} / \mathrm{kg}$ which is the separating of exchangeable acidity toxicity while the residential $(1.4 \mathrm{cmol} / \mathrm{kg})$ and industrial $(0.9 \mathrm{cmol} / \mathrm{kg})$ areas, bare $(1.0 \mathrm{cmol} / \mathrm{kg})$ and bush $(0.8 \mathrm{cmol} / \mathrm{kg})$ fallow plot recorded minimal, non-toxic exchangeable acidity. Total exchangeable basses ranged between $0.44-4.10 \mathrm{cmol} / \mathrm{kg}$. Bush fallow area recorded the highest $(4.10 \mathrm{cmol} / \mathrm{kg})$ due to high leaf litter fall and reduced mineralization of organic matter and leaching of nutrients. This was followed by the excavated site $(3.89 \mathrm{cmol} / \mathrm{kg})$ due the basic cations trapped at the exuviated horizon from leaching, now exposed by top soil removal. Oil palm plantation recorded TEB value of $3.77 \mathrm{cmol} / \mathrm{kg}$ due to palm litter deposition and decomposition. Cassava plot $(2.33 \mathrm{cmol} / \mathrm{kg})$, residential $(2.17 \mathrm{cmol} / \mathrm{kg})$, industrial $(2.02 \mathrm{cmol} / \mathrm{kg})$, bare fallow (1.99 $\mathrm{cmol} / \mathrm{kg})$ and continuous cultivation $(0.74 \mathrm{cmol} / \mathrm{kg})$ plots recorded low basic cations due to exposure of soil to intense leaching in the bare fallow, plant nutrient uptake in the cassava and continuous cultivated plots and top soil removal in the residential and industrial areas. Low $\mathrm{Na}$ observed in the areas studied also showed that the soils were non-saline. The ECEC values of all soils studied were low and ranged between $2.92-7.29 \mathrm{cmol} / \mathrm{kg}$. Table 2 .

ECEC values which range from above $8 \mathrm{cmol} / \mathrm{kg}$ are satisfactory for crop production. High annual rainfall, nature of parent material as well as top soil removal and leaching could explain the low ECEC of soils studied. All soils studied recorded \%BS values above $50 \%$, the separating index between fertile and non-fertile soils except in the continuous cultivated plot with \%BS of $26.6 \%$. \% BS at $100 \%$ usually occur at $\mathrm{pH}$ 7.0-7.2. Mores, luxurious crops are best grown at $\% \mathrm{BS}$ above $90 \%$. The total nitrogen levels observed in all soils studied were low which ranged between $0.01-0.06 \%$. The low $\mathrm{N}$ may be attributed to the sandy texture of the soils and resultant high mineralization and leaching through the soil profile. Also crop removal may have contributed to the low N values. Many crop materials contain 2-4\% Nitrogen on dry basis and when harvested, nitrogen is lost. In areas of high organic matter such as the bare fallow and bush fallow plots, loss of nitrogen could be attributed to the extreme competition between the soil microorganisms for the limited amount of soil nitrogen. These microorganisms not only compete between themselves for nitrogen, but also against crops. More so, recalcitrant organic residues may be difficult to decompose organic nitrogen, these include cellulose, lignin, oils, fat and resins. The amines and amino acids released by the process of aminization during the $\mathrm{N}$ mineralization process could be tied up to clays. The available $\mathrm{P}$ ranged between 0.72-6.77 ppm. Low $\mathrm{P}$ recorded indicated that $\mathrm{P}$ may be chemically bound as phosphate of $\mathrm{Fe}$ and $\mathrm{Al}$ due to the acid nature of the soils studied. Low $\mathrm{P}$ could be attributed to low organic matter, plant nutrient uptake and nature of the parent material.

\section{Land Degradation}

Table 3 displayed Land Degradation Index (LDI) of selected soil properties studied. Negative LDI values indicate degraded soil properties while positive LDI values indicate non-degraded soil properties. Bush fallow land use type with zero LDI values is a separating index between degraded and non-degraded soil properties. Organic matter was observed to be degraded in all areas studied except in the bare fallow area (14.2) as continuous cultivated plot (70.3) recorded the highest degradation; Hydraulic conductivity was highly degraded in all soils studied as the highest degradation rate was recorded in the excavated site $(-92.9)$ while the least was recorded in the bare fallow plot (-20.6). Total exchangeable bases were degraded in all soils studied having the highest degradation in the continuous cultivated plot (-82.0) and least in the oil palm plantation (8.0). ECEC was degraded in all soils studied except in the oil palm plantation and excavation sites having appreciation of 25.9 and 48.8, respectively. Percentage base saturation was degraded in all soils studied with continuous cultivated plot (-68.2) and industrial area (-17.3) having the highest and least degradation rate respectively. Total nitrogen showed appreciation in most soils studied except in the cassava plot (-50) and excavated site (-50). Available phosphorus was observed to be degraded in all soils, having the highest and least degradation rates at the oil palm plantation (-89.4) and excavation site (-26.1), respectively.

\section{Conclusion}

Blank utilization of lands without appropriate soil information derived from soil evaluation alters soil quality and impedes soils from performing its inherent functions. The study showed that depletion in soil quality was observed in all land use types studied when compared to the bush fallow soils. Hydraulic conductivity was low in all soils studied which could lead to flooding, erosion and pollution during intense rainfall. Soils of the bush fallow plot retained its quality due to vegetative cover, restricted leaching, reduced evaporation and reduction oxidation of organic matter. Densely populated state of tropical Nigeria has led to increased need for land hence the expansion of human activities into agricultural and forest lands which alters the soil and environment at large. However, the adoption of organic and climate smart agriculture should be highly encouraged. 


\section{References}

Akamigbo, F.O.R. 1999. Influence of land use on soil properties of the Humidtropical agro-ecology of Southeastern Nigeria. Nigeria Agriculture Journal 30: 59-76.

Arshad, M.A., B. Lowery and B. Grossman. 1996. p.123141. In: Physical tests for monitoring soil quality. Methods for assessing soil quality. S. Segoe (ed.). Society of Soil Science America, Madison, USA.

Barrow, C.J. 1991. Land degradation: Development and breakdown of terrestrial environments: Cambridge University Press, United Kingdom. p.305.

FAO. 1984. Guidelines for land use planning. FAO Development Series. FAO, Rome. p.96.

Gee, G.N. and D. Or. 2002. p.225-293. Particle size analysis. In: Methods of soil analysis. D.I. Dan and G.C Topps. (eds.). Soil Science Society of America book series, Madison.

Grossman R.B and T.G. Rernisch. 2002. p.631-641. In: Methods of Soil Analysis. J.H. Dane and G. Clarke (eds.). Soil Science Society of America, Madison, Wisconsin, USA.

Jackson, M.L. 1964. Chemical composition of soil. p.71144. In: chemistry of soil. F.E. Bean Van Nostrand (ed.). City publisher, New York.

Lal, R. 1993. Tillage effects on soil degradation, soil resilience, soil quality and sustainability. Soil Tillage Research 27:1-8.

Mclean, E.O. 1982. Soil pH and lime requirement. p.199. In: Methods of soil analysis, part 2. C.A. Black (ed.). American Society of Agronomy and Soil Science Society of America, Madison, Wisconsin, USA.

Negassa, W. 2001. Assessment of Important Physicochemical Properties of Nitosols under Different Management Systems in Bako Area, Western Ethiopia. M.Sc. Thesis, Alemaya University, Alemaya. p.109.
Nelson, D.N and L.E. Sommers. 1982. p.539-579. Total carbon, organic carbon and matter. In: Methods of Soil Analysis part 2. A.D. Miller and D.K.M. Keeney (eds.). American Society of Agronomy. Madison, Wisconsin, USA.

Obi, M.E. 2000. p.148. Soil Physics: A compendium of lecturers. Nsukka, Atlanto publishers, Nigeria.

Olsen, S. and I.E. Sommers. 1982. Nitrification in duch heathland soil. Plant and Soil 127: 179-192.

Ofomata, E.K. 1975. Nigeria in maps. Eastern States, Ethiope Publishing House, Benin City, Nigeria.

Senjobi, B.A. and A.O. Ogunkunle. 2011. Effect of different land use types and their implications on land degradation and productivity in Ogun State, Nigeria. Journal of Agricultural Biotechnology and Sustainable Development 3: 7-18.

Soil Survey Staff. 2003. Keys to Soil Taxonomy. $9^{\text {th }}$ Ed. USDA National Resource Conservation Service, Washington DC, USA.

Soil Survey Laboratory Staff .1992. Soil Survey Laboratory Methods Manual. 2 ${ }^{\text {nd }}$ Ed. United State Govt. Print. Offices Washington, DC. p.400.

Thomas, G.W. 1988. Beyond the exchangeable Aluminum: Another ride on the merry-go-pound. Communication in soil science and plant analysis 19: 833-856.

Wilding, L.P. 1994. Soil testing: For improving nutrient recommendation. Soil Science Society of America and American Society of Agronomy. Madison, Wisconsin, USA. p. 220 .

Wilson, B.R., G. Ivor and J. Lemon. 2008. Land-use effects on soil properties on north-western slopes of New South Wales: implication for soil conditions assessment Australian Journal of soil research. 46(4): 359-367.

World Bank .2001. Making Sustainable Commitments: An Environment Strategy for the World Bank, http://www.worldbank.org/environment/. 